\title{
„Učitelky“: jejich dlouhá cesta k rovnoprávnosti a uznání se zaměřením na feminizaci a její důsledky ${ }^{1}$
}

\author{
Renate Seebauer \\ Pädagogische Hochschule Wien, Institut Allgemein bildende Pflichtschulen
}

Redakci zasláno 23. 3. 2014 / upravená verze obdržena 15. 10. 2014 /

k uveřejnění přijato 30.10. 2014

\begin{abstract}
Abstrakt: Vycházeje z aktuální situace v oblasti feminizace na rakouských školách, bude v historické studii zahrnující časové rozmezí od r. 1870 do konce první světové války načrtnuta dlouhá cesta učitelek k rovnoprávnosti a uznání, jak ji lze sledovat v historických odborných pedagogických časopisech. Kořeny feminizace, především v oblasti primární školy, sahají hluboko do 19. století (tehdy školy obecné Volksschule). Přes veškeré překážky ze strany mužských kolegů a obtížné pracovní podmínky bylo až do roku 1896, kdy byly dívky/ženy poprvé připuštěny ke složení maturity, povolání „učitelky“ jedinou možností, jak mohly dosáhnout uznávaného vzdělání, které přesahovalo rámec povinné školní docházky. Během krátké doby tudíž vzdělávací ústavy „vyprodukovaly“ nadbytek učitelek, které se často musely jako soukromé učitelky za „skývu chleba“ tvrdě protloukat životem. Dnešní vysoká míra feminizace, jejímž důsledkem je nedostatek mužů na rakouských primárních školách, oslabuje především u chlapců možnost setkávat se s příklady mužských rolových vzorů; chlapci tak v dětském věku nenacházejí modely chování příslušníků stejného pohlaví, se kterými by se mohli identifikovat; zdá se, že chlapci s migračním pozadím - speciálně z jiných kulturních kruhů - jsou tím obzvláště postiženi. Argumentace podložené teorií genderu ukazují na rozmanitost důvodů, proč v učitelském povolání vládne feminizace a proč jen málo mužů volí studium učitelství pro primární školu. Mnohé jevy, se kterými se v nejnovějších studiích setkáváme (obsazování vedoucích míst, aspekty pracovní psychologie...), nacházíme již v pojednáních z let na přelomu mezi 19. a 20. stoletím.
\end{abstract}

Klíčová slova: feminizace, diskriminace, rovnoprávnost, celibát učitelek, vysvětlení vycházející z genderové teorie

Autorka věnuje predložený př́spěvek panu profesoru Josefu Maňákovi z Pedagogické fakulty Masarykovy univerzity k jeho 90. narozeninám - s upř́mnou úctou.

1 Poznámka redakce: Jedná se o překlad originálního (dosud nepublikovaného) textu z německého jazyka, překlad provedl Pavel Váňa z Katedry německého jazyka a literatury PdF MU a Tomáš Janík z Institutu výzkumu školního vzdělávání PdF MU. 


\section{Prolog: K aktuální situaci v Rakousku}

V předkládané studii se zabýváme otázkou feminizace ve školách v Rakousku. Podle přehledů zveřejněných Statistik Austria ${ }^{2}$ (2013) tvoří více než dvě třetiny učitelského personálu na rakouských školách ženy. V oblasti primárních škol činí jejich podíl na celkovém učitelském personálu okolo $92 \%$. V učitelském personálu škol připravujících na povolání však existuje téměř rovnost zastoupení žen a mužù. Podíl v jednotlivých odvětvích školství připravujícího na povolání je značně rozdílný: podíl žen v rámci učitelského personálu na školách se zaměřením na hospodářská povolání činí 80 \%, na technických školách a školách pro jednotlivá řemesla je naproti tomu cca $26 \%$ žen. Na veřejných univerzitách byl ve studijním roce 2012/2013 podíl žen 39 \%; ve skupině profesorů a profesorek jsou však ženy zastoupeny pouze 22 \% (Statistik Austria, 2013). Pro školní rok 2012/13 přinesla Statistik Austria (2013) k učitelskému personálu na jednotlivých typech škol údaje prezentované $\mathrm{v}$ tabulce 1 .

Tabulka 1

Počty učitelek a učitelů dle typu školy

\begin{tabular}{llcc}
\hline Typ školy & & Ženy & Muži \\
\hline Primární školy & 1.-4. ročník & 30330 & 2672 \\
Hlavní školy/Nové střední školy & 5.-8. ročník & 21041 & 7953 \\
Speciální školy & 1.-8./9. ročník & 5542 & 815 \\
Polytechnické školy & 9. ročník & 1326 & 997 \\
$\begin{array}{l}\text { Všeobecně vzdělávací vyšší školy } \\
\text { (dlouhá forma tzv. gymnázia) }\end{array}$ & 5.-12. ročník & 14116 & 8063 \\
\hline
\end{tabular}

Pozn. Upraveno podle Statistik Austria (2013).

Stran obsazení škol vedoucími pracovníky je třeba konstatovat, že zatímco učitelky dosahují vedoucí pozice pouze ve $4 \%$, u učitelů je to $9 \%$. Na primárních školách je vedoucí funkce svěřena každému čtvrtému muži, ale pouze přibližně každé čtrnácté ženě (srov. Bruneforth, Herzog-Punzenberger, \& Lassnigg, 2013, s. 7).

2 Uvádím zde údaje, které jsme převzali z rakouského statistického ústavu/portálu v němčině označovaného jako „Statistik Austria“. 
I když jsou k dispozici různé př́istupy $\mathrm{k}$ vysvětlení fenoménu feminizace, budou na tomto místě detailně představeny některé historické aspekty jevící se jako charakteristické pro Rakousko, resp. pro korunní země bývalé „dvojí monarchie Rakousko-Uhersko“.

\section{K historickému kontextu}

V dnešní době vedou často ke změně přístupů ve vzdělávání nelichotivé výsledky šetření PISA; před 150 léty to kupodivu byli rakouští vojáci odvodového ročníku 1865, kteří byli - na rozdíl od pruských vojáků - ze dvou třetin analfabety, a zavdali tak přícinu ke zdrcující kritice, jež se poté na školství snesla. Následoval tolik potřebný Říšský zákon o obecných školách ${ }^{3}$ (1869). De iure zavedl společnou veřejnou školu pro všechny školou povinné a vytvořil pro učitele a učitelky - zřízením učitelských ústavů pro jejich vzdělávání - co nejširší možnost stejného vzdělávání. De facto však docházelo k projevům výrazného odporu vůči tomuto modernímu zákonu, který mj. vytvořil novou profesní skupinu - učitelky se stejnou kvalifikací jako měli jejich mužští kolegové - která pronikla do povolání, v němž dosud dominovali muži. Boje o profesní uznání, rozdílné argumentační linie diskriminace, ukládání celibátu (s rozličným přístupem v jednotlivých korunních zemích), boj o stejnou odměnu za stejnou práci a adekvátní možnosti kariérního postupu pro učitelky, nebyly pouze „otázkou učitelek“, nýbrž se během let staly „ženskou otázkou" jako takovou.

V předkládané studii, která se opírá o historické pedagogické odborné časopisy a zahrnuje přibližně období od roku 1869 do konce první světové války bude pozornost upřena na tyto otázky:

1. Jaké změny znamenal pro učitelky Říšský zákon o obecných školách (1869) de iure?

2. Jaké kritice a jaké diskriminaci byly učitelky na rozdíl od učitelů vystaveny?

\footnotetext{
Poznámka redakce: Reichsvolksschulgesetz 1869 - Zákon říšský ze dne 14. m. května 1869 koncipovaný Leopoldem Hasnerem von Artha. Obsahoval prodloužení školní docházky na osm let; zaváděl obecnou školu (Volksschule) a měštanskou školu (Bürgerschule); měl také za cíl zlepšit učitelské vzdělávání. Je-li v tomto textu použito termínu obecná škola, jde o předklad termínu Volksschule. Tehdejší Volkschule - obecná škola, odpovídá dnešnímu prvnímu stupni základní školy, tj. škole primární. $K$ dalším stupňům a typům škol viz Tabulka 1.
} 


\section{Jaké postoje byly zaujímány vůči celibátu - i mezi učitelkami?}

Autorce tohoto př́íspěvku velmi záleží na tom, aby dala prostor k vyjádření angažovaným ženám, především učitelkám, s cílem ukázat, jak myslí, žijí, cítí... Ke slovu přijdou i mnohé z nich, které nejsou uvedeny jmenovitě, nebot' se k zveřejnění svého jména neodhodlaly.

\subsection{K první otázce: právní změny po vydání Říšského zákona o obecných školách}

Dne 14. května 1869 sankcionoval císař Řišský zákon o obecných školách vytvořený ministrem školství Leopoldem Hasnerem von Artha. Zákon zřizoval mj. Ústav pro vzdělávání učitelek za účelem vzdělávání učitelek pro výuku na obecné škole. Vzdělávání mělo zahrnovat čtyři ročníky. Nástup na školu byl možný po dosažení věkové hranice 15 let po přísné přijímací zkoušce, která se vztahovala na předměty nižšího stupně gymnázia. Čtyřleté vzdělávání byla ukončeno „zkouškou zralosti“ (ovšem bez oprávnění ke studiu na vysoké škole).

Zkouška učitelské způsobilosti (Lehrerbefähigungsprüfung) mohla být složena po dvouleté praxi na škole a byla předpokladem k získání definitivního umístění na obecné škole (Volksschule). Ke složení zkoušky na měštanské škole (Bürgerschule) se vyžadovala nejméně tř́letá praxe; příprava na tuto zkoušku mohla probíhat formou samostudia ve zvláštních kurzech. Skutečnost, že bylo vzdělávání učitelů a učitelek rozšířeno na čtyři roky teprve ve školním roce 1872/73 ukazuje, že k uskutečňování zákonných změn docházelo jen pozvolna.

Státní ústav pro vzdělávání učitelů zahájil výuku 15. prosince 1869. Do druhého ročníku bylo přijato 40 studujících v preparandách sv. Uršuly pro vyšší oddělení, do prvního ročníku bylo po složení přijímací zkoušky přijato 40 chovanek.

Vzhledem k pozitivním novinkám, které přinesl Říšský zákon o obecných školách, nelze bez bližší znalosti situace pochopit razanci, s jakou se proti němu bojovalo. Federalisté se domnívali, že návrh zákona operuje s př́liš detailními ustanoveními a nebral by tedy $\mathrm{v}$ potaz rozdílnosti mezi jednotlivými korunními zeměmi; klerikálové si nedokázali představit školu bez úzké vazby na náboženství a církev a další skupina protivníků byla toho názoru, že pro takový zákon ještě neuzrál čas a že nejsou dány předpoklady pro jeho provedení, přestože usiluje o dosažení pozitivních cílů. 
Námitky protivníků neutichaly; konzervativní většina 170 proti 167 hlasům si 2 . května 1883 vynutila novelu školského zákona s následujícími konsekvencemi pro vzdělávání učitelů a učitelek: úprava podmínky přijetí na učitelský vzdělávací ústav snížením požadovaných znalostí na úroveň měštanské školy; zmírnění požadavků na učitele; zostření kontroly učitelů týkající se jejich chování mimo školu; dosažení místa ředitele školy mělo být závislé na způsobilosti vyučovat většinu žáků náboženství. Tím se připuštění k postu ředitele školy stalo závislým na církevních úřadech. Je zcela zřejmé, že ve chvíli, kdy Říšský zákon o obecných školách vstoupil v platnost, nebyl potřebný počet adekvátně vzdělaných učitelů a učitelek $\mathrm{k}$ dispozici. $\mathrm{V}$ článku Die guten Prüfungsresultate der Lehrerinnen - Dobré výsledky zkoušek u učitelu (0. A., 1879) se o mužských kandidátech na učitelský úřad hovoří jako o „neštastných existencích“, které

za sebou mají často pohnutý život, pokoušeli se pracovat v nejrůznějších odvětvích a nakonec se chopili učitelství jako třináctého řemesla. Muži ve výrazně pokročilém životním stadiu, ve věku od 40 do 60 let, ženatí a požehnaní dětmi. Na základě své víceleté školní praxe dosahují připuštění ke zkoušce učitelské způsobilosti, aniž by při svém nedostatečném předchozím vzdělání měli tu nejmenší vyhlídku na úspěch, a dostaví se pak ke zkoušce podruhé, ba i potřetí. V mnoha př́padech se bere ohled až k nejzazší mezi zákona. (s. 19)

Tento podrobně citovaný článek charakterizuje nejen situaci ve školství kolem roku 1875, nýbrž lze ho rovněž chápat jako odpověd' na dobré výsledky zkoušek ve skupině ženských kandidátek na učitelský úřad, které neustále skýtaly prostor k útokům na učitelky ve školách - v tom smyslu, že se zkoušejícím vyčítala "galantnost vůči slabému pohlaví“ (O. A., 1879, s. 19).

Vídeňský obecní rada Raffelsberger požadoval již v roce 1862, aby na dívčích školách byly přednostně zaměstnávány učitelky. Tato zásada se sice v některých dolnorakouských obcích začala uplatňovat, ale naproti tomu ve Vídni byla uskutečněna teprve $\mathrm{v}$ roce 1871 , kdy došlo poprvé $\mathrm{k}$ obsazení učitelských míst ženami.

Österreichische Lehrerinnen-Zeitung - Rakouský učitelský časopis poukazuje ve vydání z 15. ledna 1899 na vývoj zaměstnávání učitelek:

v roce 1871 bylo v Rakousku z celkového počtu vyučujících 7,8\% žen, v roce $18759,8 \%$, v roce $188015,4 \%$, v roce $188517,6 \%$ a v roce $189018,8 \%$. Ve Vídni je [1899] na obecných a měštanských školách 1445 učitelek, což je 37 \% z celkového počtu vyučujících. Z toho působí cca 150 na měštanských, 1300 na obecných školách. K tomuto počtu je třeba ještě přičíst 410 učitelek průmyslových oborů a 107 učitelek francouzštiny. (cit. podle Kraus, 1900, s. 430) 
Většina učitelek pocházela z městských rodin, což mělo za následek, že se ve městech projevoval rychlejší přírůstek učitelek než na venkově. Na mnoha jednotř́dkách na venkově působili - s výjimkou Tyrolska a Vorarlbergu - výhradně učitelé (srov. Kraus, 1900, s. 429). Mezi vyučujícími ženami v Předlitavsku ${ }^{4}$ se nacházelo $\mathrm{v}$ roce 1890 celkově 365 jeptišek, z toho v Tyrolsku 218, ve Vorarlbersku 63; v Horních Rakousích a Salzbursku naproti tomu pouze po jedné (srov. Kraus, 1900, s. 435).

Ustanovení, že „učitelky mohou vyučovat rovněž na chlapeckých školách“ (povšimněme si typické formulace s výrazem „mohou“), ponechalo zemskému zákonodárství možnost vydat k této záležitosti (tzn. k § 16 Říšského zákona o obecných školách z roku 1869) bližší směrnice, což vedlo v jednotlivých korunních zemích k různým interpretacím. V Dolních Rakousích byly učitelky připuštěny k vyučování ve čtyřech nižších chlapeckých třídách (zákon z 5. dubna 1870, § 38); stejně tak v Horních Rakousích, Salzbursku, ve Štýrsku a Vorarlbersku (srov. Kraus, 1900, s. 438). Naproti tomu v Tyrolsku „mohou být smíšené třídy pro čtyři nejnižší věkové skupiny obsazeny učitelkami, zatímco učitelská místa ve chlapeckých školách je třeba obsadit pouze učiteli a v dívčích školách zpravidla učitelkami (Kraus, 1900, s. 429).

Zajímavé je dále také služebně-právní postavení mužského a ženského učitelského personálu: na vedoucích místech působilo v roce 1890 97,6 \% učitelů a 2,4 \% učitelek; z definitivních učitelských míst bylo $83 \%$ obsazeno muži a 17 \% ženami. Jestliže ze 100 mužů jich 20,7 bylo na vedoucí pozici, zatímco u žen to bylo pouze 1,3 ze 100 , pak je méně výhodná pozice vyučujících žen evidentní (srov. Kraus, 1900, s. 433).

\subsection{K Kruhé otázce: kritika a diskriminace - odpověd' učitelek}

Sotva opustily první učitelky vzdělávací učitelské ústavy, ozvaly se proti nim kritické hlasy: tak např́klad Freie Schulzeitung - Svobodné školské noviny (vycházely v Aussig, dnes Ústí nad Labem) několikrát vystoupily proti učitelkám. Šlo především o tři skutečnosti, které kritikové učitelkám nemohli odpustit: zrovnoprávnění v oblasti platu, osvobození od zkoušky z trigonometrie a lepší výsledky zkoušek (srov. Bachmann, 1877, s. 121). Proti tomu se dalo namítnout, že muži studující učitelství - oproti ženám - neabsolvovali vzdělávání v ženských ručních pracích (šití v ruce a na stroji, zhotovování ozdobných pletacích a háčkovacích vzorků, umělecky ozdobené sítované práce;

4 Neoficiální označení severní a západní části Rakouska-Uherska. 
různé druhy vyšívání). Lepší výsledky zkoušek vysvětluje Bachmann (1877) sociálním postavením učitelek, díky němuž jsou odkázány na život v domácnosti:

[učitelka] nemůže a nesmí své volné chvíle trávit v kruhu přátel holdujících karetním hrám, v hostincích nebo na jiných místech zasvěcených Gambrinovi5; mají tudíž dlouhé večery na to, aby pročítaly školní sešity, připravovaly se na př́ští školní den a ještě jim zbývá čas na řádnou př́ípravu ke zkoušce učitelské způsobilosti a k práci na svém dalším vzdělávání. (s. 122)

Schmidtová (1877) uvádí ve svém článku Lehrer und Lehrerinnen in einem Lehrkörper - Učitelé a učitelky v učitelském sboru, že je „přirozené“, že učitelé a učitelky působí vedle sebe nejen na dívčích školách, nýbrž na každé škole:

muži získali jemnější a ženy pevnější přístup, myšlenky jedněch byly bohatší, druhých hlubší, muži byli pružnější, ženy rozvážnější, jedni silnější, druzí nezištnější, všichni však vděční za poznání vzájemného obohacení. [...] Takový učitelský sbor [...] bude stále častější [...]. Pouze tímto způsobem se bude vzdělání obou lidsky krásně rozvíjet... (s. 31)

Jestliže se „časopisy pro učitelky“ snažily popsat, vysvětlit a ospravedlnit působení učitelek na školách, pak byly tyto publikace přece jen dostupné relativně omezenému čtenářskému publiku. Naproti tomu denně vycházející noviny měly široké pole působnosti a byly zčásti toho ražení, že práci učitelek líčily nesprávně nebo je diskriminovaly.

V článku Die Lehrerin als Amtskollegin - Učitelka jako kolegyně v úřadu (1879) se sice „výchovný vliv ženy" v zásadě hodnotí pozitivně, ale učitelce se upírá schopnost odpovídajícím způsobem vyučovat a vychovávat děti na vyšších školních stupních:

nebot' výchovný vliv ženy se uplatňuje především tam, kde se dá mysl mládeže ještě snadno usměrňovat a výuka se omezuje na jednoduché prvky vědění. Toto tvrzení bude všeobecně platit tak dlouho, dokud se povaha ženy nezmění a vědecké vzdělávání našich učitelek nebude uspíšeno vyššími vyučovacími ústavy pro dívky... (s. 4)

Také v tomto textu se nepřímo poukazuje na lepší výsledky kandidátek při zkouškách učitelské způsobilosti tím, že jsou zkušební komisaři podezíráni ze „shovívavějšího přístupu ke kandidátkám než ke kandidátům“ (s. 4), což konec konců vede ke zničujícímu odmítnutí odborné kompetence učitelek:

5 Gambrinus je legendární král, který je považován za vynálezce pivovarnictví. 
na tomto místě vůbec nechci vyzdvihovat moment učitelské zkoušky pro ženská učitelská individua, nýbrž pouze výkonnost učitelek, které bych $\mathrm{v}$ průměru vykázal do nižších tříd našich obecných a měštáanských škol jako do oblasti působení, která jim přísluší. Přímo nesmyslné (Nonsens) mi však připadá použít učitelky na vyšších stupních vzdělávacích institucí. (s. 4)

Jako třetí bod své kritiky uvádí autor nepř́ípustnost, aby „soudržky v úřadu“ měly „poradní a rozhodovací hlas na konferencích příslušného učitelského sboru“

ze zkušenosti musíme bohužel přiznat, že právě zde se opět nepříznivě projevuje zvláštnost ženské povahy, kdy nedostatek objektivního pohledu na věc, nesamostatnost a poddajnost ženského charakteru tento charakter nečiní zcela schopným vykonávat praktickou učitelskou práci. (s. 4)

Učitelkám se též vyčítá, že mají menší radost z povolání než učitelé (tamtéž, s. 4). Masivní diskriminace byla evidentní i v systému odměňování, kdy se s podučitelkami (Unterlehrerinnen) zacházelo jako s námezdními pracovnicemi. Po absolvování vzdělávacího ústavu pro učitele začala pro mnohé mladé učitelky trnitá cesta. Musely čekat, až budou „povolány“. Současně se měly připravovat na zkoušku učitelské způsobilosti, aby mohly postoupit do vyššího platového stupně; složení této zkoušky bylo ovšem možné teprve po absolvování dvou let praxe.

V jednom článku z 6. ledna 1898 se tématem špatného odměňování učitelek obecných škol zabývají také noviny Arbeiterinnen-Zeitung - Časopis pracovnic:

nejhůře se vede těm, které musejí ze svého nízkého platu ještě vydržovat sourozence, podporovat rodiče, nebo přinejmenším přispívat na domácnost - a těch není zrovna málo. $V$ takovém př́ípadě nezbývá nic jiného, než vyplnit každou volnou chvíli udílením soukromých lekcí a nahradit tak chybějící finance [...]; odměna za tuto činnost je však u drtivé většiny podučitelek stejná jako odměna proletářky. (Virgo, 1898, s. 2)

„Povolání" znamenalo použití mladé učitelky comunou (zde obec Vídeň) pro školní službu, což ovšem - často po celá léta - neznamenalo trvalé zaměstnání. „Létající psi“, jak byly školním žargonem nazývány, (dnes „suplovací rezerva") - tyto učitelky se musely hlásit na radnici a byly nasazovány jako výpomoc za onemocnělé kolegy. ${ }^{6}$

Učitelé a učitelky př́slušné školy musely bezplatně suplovat za onemocnělé kolegy nebo kolegyně po dobu až čtyř týdnů. Teprve poté mohla škola požádat o výpomocnou sílu (srov. Eine Lehrerin. Unterlehrerinen, 1899, s. 12). 
Hned učí na této škole, hned nato na jiné, tu v Ottakringu, tam zase v Unterdöblingu nebo Favoriten, a tak je hnána z jednoho konce na druhý; výuka na jedné škole trvá jen pár dnů nebo týdnů. (Eine Lehrerin, 1899, s. 11)

Mezi výukou na různých školách bylo často období dnů nebo týdnů bez práce. „Denní mzda“ byla propočítána podle ročního platu podučitelek (400 zl.), které ještě nesložily zkoušku učitelské způsobilosti; pokud ji již složily, byla vypočtena ze základu 600 zl. 1. ledna 1896 došlo na základě „,substitučního normálu" $\mathrm{k}$ dalšímu zhoršení. Př́ijem pomocné učitelky dosahoval v přepočtu na den 1 zl. 16 kr., případně 1 zl. 33 kr. (srov. Eine Lehrerin, 1899, s. 11).

U podučitelek bylo třeba rozlišovat mezi „systemizovanými“ a „nesystemizovanými místy“. Pokud měla provizorní podučitelka systemizované místo, dostávala placené prázdniny. Učitelky, které měly nesystemizované místo, obdržely roční příjem nižší o $100 \mathrm{zl}$.

V článku Eine Lehrerin. Unterlehrerinnen - Učitelka. Podučitelky (1899) je porovnáváno 50 provizorních podučitelek se šesti až 16 služebními léty se 76 podučitelkami s definitivou se čtyřmi až šesti služebními léty. Pokud podučitelka složila zkoušku na měštanskou školu, měla sice vyhlídku na vyšší př́ijmy (100 zl. nebo 200 zl.), ale třeba i navzdory definitivě pro ni začínal opět od začátku život létajícího psa / výpomocné síly - suplovala na měšt’anských školách.

Tabulka 2 ukazuje rozložení příjmů pod existenčním minimem $600 \mathrm{zl}$. ve srovnání učitelů a učitelek v procentech ve vybraných korunních zemích.

Tabulka 2

Rozložení př́imů pod existenčním minimem: srovnání mužů a žen

\begin{tabular}{lcc}
\hline Př́́jem pod 600 zl. & Ze 100 učitelů (v \%) & Ze 100 učitelek (v \%) \\
\hline Dolní Rakousy & 15,8 & 14,9 \\
Horní Rakousy & 19,9 & 45,7 \\
Salcbursko & 43,2 & 71,7 \\
Štýrsko & 28,3 & 68,7 \\
Korutany & 46,5 & 84,4 \\
Tyrolsko & 92,2 & 99,8 \\
Vorarlbersko & 81,4 & 100,0 \\
\hline
\end{tabular}

Pozn. Upraveno podle Kraus (1900, s. 438); Schmidt (1887), Zeitschrift für Volkswirtschaft, Sozialpolitik und Verwaltung (1896, sv. V, sešit 2).

Krajně problematickou situaci učitelů a učitelek v obecních školách v mnoha korunních zemích ilustruje Kraus (1900) velmi transparentně: 
V prosinci 1891 zemřely [...] dvě osoby učitelského povolání hladem. V Gronkowě (okres Nowy Targ) to byla 17. prosince 1891 sedmnáctiletá slečna Korczynska, která byla zaměstnána $\mathrm{v}$ tamní veřejné obecné škole se 16 zl. měsíčně, a v Bubsczani u Pomorze 13. prosince 1891 24letý učitel v obecné škole [...], jehož měsíční plat obnášel $17 \mathrm{zl}$. V obou př́ípadech bylo ze strany lékaře konstatováno úmrtí hladem. (Volkstribüne, 1892, č. 7, cit. podle Kraus, 1900, s. 439)

To bylo možné v Haliči, korunní zemi, kde plat pro provizorní učitele dle zákona z 1. ledna 1889 nesměl být nižší než 250 zl. (Österreichische Statistik, 1895, svazek XLII, sešit 1, cit. podle Kraus, 1900, s. 439).

První učitelky, které v létech 1869 až 1871 nastoupily do školní služby ve Vídni, dostávaly pouze $80 \%$ učitelského platu s odůvodněním, „že [učitelky] potřebují méně “7 , což je zdůvodnění, které se používalo i později. Po několik let existovala v odměnách rovnoprávnost, ale po úpravě z 22. prosince 1885 klesly př́ijmy učitelek ${ }^{8}$ na 95,5-88,80 \% př́ijmů učitelů!

Teprve platební zákon z 26. srpna 1910 znamenal pro dolnorakouské učitelky zrovnoprávnění, jak v oblasti základního platu, tak v příplatcích podle služebního věku. I když nyní vídeňští vyučující obojího pohlaví pobírali stejný základní plat, propočítávaly se příplatky související se služebním věkem rozdílně a př́íspěvek na bydlení byl pro učitelky o čtvrtinu až polovinu menší než v př́ípadě učitelů (srov. Borschitzky, 1911, s. 2). K situaci v korunních zemích Borschitzky (1911) uvádí:

Dokonce v Dalmácii, kde se na ženu pohlíží víceméně jako na tažné zvíře, dostává učitelka $80 \%$ platu učitele a stejně velký byt. Čechy, Morava, Slezsko, Halič a Bukovina vyplácejí učitelům i učitelkám plat ve stejné výši. V Salcbursku dostávají učitelky $90 \%$ platů učitelů a stejně velký př́íspěvek na ubytování jako učitelé. Ve Štýrsku, Horních Rakousích a ostatních korunních zemích dochází v mnohém ohledu k rozdílům, které však nikdy nepřesáhnou $20 \%$. Pouze Tyrolsko vyměřuje učitelkám, mezi nimiž se však nachází na 500 řádových sester, plat ve výši $75 \%$ platu učitele. (Borschitzky, 1911, s. 4)

Jako odůvodnění lepšího platu učitelů mužů se uváděly potřeby otce rodiny. Ovšem vyšší př́ijmy pobírali nejen všichni katoličtí učitelé náboženství, ale i každý neženatý učitel (Die Gehaltsregulierung und die Wiener Lehrerinnen, 1912).

8 Prausek, označovaný často za podporovatele učitelek, navrhl platové schéma pro učitele a učitelky již v roce 1868 - tedy rok před zavedením Říšského zákona o obecných školách. Počítalo se s tím, že první učitel/ředitel obdrží roční plat 700 zl., katecheta 600 zl., druhý učitel 600 zl., třetí učitel 500 zl. ... Pro ženský učitelský personál mělo platit následující schéma: první učitelka obdrží 500 zl., druhá učitelka 450 zl., třetí učitelka 400 zl. ... (srov. Prausek, 1868, s. 204). První učitelka měla tedy vydělávat tolik, jako třetí učitel! 
I když byly kolem roku 1910 platy učitelů navýšeny o $16 \%$, zvýšily se platy učitelek pouze o 8\%; při zvýšení cen potravin a jiného zboží o 20-25\% (srov. Schwarz, 1910, s. 3; Nauheimer, 1912, s. 8).

Otázka platů učitelek se v těchto létech čím dál více stávala všeobecně ženskou otázkou; na shromážděních zdůrazňovaly učitelky nutnost dosažení ženského volebního práva, které $\mathrm{v}$ Rakousku obdržely v souvislosti se zavedením všeobecného volebního práva 12. listopadu 1918. Učitelky byly po platové stránce zrovnoprávněny s muži teprve se založením první rakouské republiky v roce 1918. Jejich šance služebního postupu se však vydáním Řišssého zákona o obecných školách změnily jen málo.

V souvislosti s obsazováním míst jsou k dispozici následující data: $\mathrm{z}$ veškerých dívčích škol ve Vídni jsou jich jen $4 \%$ vedeny ženami, zatímco učitelky tvoří ve Vídni $42 \%$ z celkového počtu vyučujících. Podle toho by bylo celkem $98 \%$ vedoucích míst obsazeno muži (viz Der Gleichberechtigungskampf, 1913, s. 2). Dle Ř́šssého zákona o obecných školách z roku 1869 byly učitelky oprávněny ke stejným nárokům jako učitelé (Hany, 1912; 0. A., 1914). Upřednostňování učitelů před učitelkami při udílení místa nebylo - jak zjistil Schwarz v roce 1914 - ničím zásadně novým: „Nikoli vědomosti a um, nikoli vhodnost a důstojnost, nýbrž hlavně stranické důvody jsou pro upřednostnění rozhodující." Další kritika se obrací proti textům konkurzů, ve kterých je ve Vídni běžná varianta: „zaměstnání pro učitele“ místo „zaměstnání pro učitelku, příp. učitele“ nebo „zaměstnání pro učitele, př́íp. učitelku“ - v důsledku čehož nebyly do návrhu na vypsaná místa přijaty žádné učitelky (Zur Besetzung der Lehrerstellen in Wien, 1895, s. 202).

\subsection{K třetí otázce: celibát}

Deset let po nabytí platnosti Říšského zákona o obecných školách jsou výpady vůči učitelkám četnější než v letech předchozích. Vyčítá se jim, že „neustále s potěšením využívají příležitosti vdát se a pak vystoupí z učitelského stavu“ (Wichodil, 1879, s. 161). Jako důvod se neuvádí celibát učitelek, nýbrž jejich menší „radost z povolání“. Wichodil (1879) se pokouší reagovat na tyto výtky, staví je do protikladu s číselnými údaji statistiky a referuje, že „ze 100 učitelek v tak zvaném věku, kdy lze uzavřít sňatek, [...] se ročně vdají sotva více než čtyři“" (Wichodil, 1879, s. 161), což podle něj neukazuje na nedostatečnou radost z povolání. 
V průběhu diskuze - učitel nebo učitelka - se koncem roku 1870 poprvé objevuje aspekt výkonu; také Blaschke (1880) uvádí, že není třeba diskutovat o tom, zda „je učitelka paní nebo slečnou [...], pokud vyhovuje veškerým požadavkům kladeným na ni ze strany učitelského povolání" (s. 175). Celibát učitelek se zdůvodňuje udržením „řádného vyučovacího provozu“. Ve věci sňatků učitelek platila $\mathrm{v}$ jednotlivých korunních zemích rozdílná ustanovení, což pro rok 1890 dokládá tabulka 3.

Tabulka 3

Počty vdaných, ovdovělých a separovaných/rozvedených učitelek ve vybraných spolkových zemích (1890)

\begin{tabular}{lcccc}
\hline & \multicolumn{2}{c}{ Počet učitelek } & \multicolumn{2}{c}{ Ze 100 učitelek bylo } \\
\cline { 2 - 5 } Země & vdaných & $\begin{array}{c}\text { ovdovělých či } \\
\text { separovaných/ } \\
\text { rozvedených }\end{array}$ & vdaných & $\begin{array}{c}\text { ovdovělých či } \\
\text { separovaných/ } \\
\text { rozvedecných }\end{array}$ \\
\hline Dolní Rakousy & 311 & 33 & 22,5 & 2,4 \\
Horní Rakousy & 30 & 3 & 11,5 & 1,2 \\
Štýrsko & 57 & 9 & 13,5 & 2,1 \\
Korutany & 3 & 2 & 2,9 & 1,9 \\
Tyrolsko & 56 & 16 & 5,1 & 1,4 \\
\hline
\end{tabular}

Pozn. Upraveno podle Kraus (1890, s. 436); jedná se o výběr některých dnešních spolkových zemí.

V Salcbursku a Vorarlbersku byl sňatek považován za vypovězení služby. Kuriózně se vyjímá štýrský § 12 zákona z 19. září 1899, v němž se praví:

Sňatek ř́́dící učitelky nebo učitelky je třeba považovat za dobrovolné vypovězení služby. Výjimečně může zemský školní rada po slyšení místního a okresního (prrípadně městského) školního rady ve zvláště citlivých př́padech udělit povolení ke sňatku ř́́dící učitelky nebo učitelky s učitelem. (cit. podle Kraus, 1900, s. 436)

Za rok 1897 je pro oblast Vídně uvedeno 1481 učitelek, z nichž 411 (tj. 27,75\%) bylo provdáno (Kraus, 1900, s. 437).

Dolnorakouský zemský sněm se zabýval v roce 1901 rozpravami o penzijním zákonu pro učitele, přičemž byl $\mathrm{k} \S 2$ připojen odstavec, podle kterého „sňatek učitelky bude považován za dobrovolné vypovězení služby" (Von einer Lehrerin, 1901, s. 270). Přímý podnět k vydání takových ustanovení se nesnadně zjištujuje, avšak kolem roku 1900 jsou odůvodňována „výhodností 
pro zajištění spořádaného vyučování ve veřejné obecné škole“, k čemuž citovaný článek podává vysvětlení, že „provdaná učitelka se před a po svém slehnutí (Niederkunft) po určitou dobu nemůže výuky zúčastnit, a tím by byl řádný vyučovací provoz narušen".

K tomu je připojena kritická poznámka:

Pokud v nějakém př́padě dojde ke konfliktu mezi osobní svobodou a požadavky povolání, pak se moderní cítění rozhodne vždy tak, že tímto konfliktem nemá trpět osobnost, nýbrž povolání, a př́padným škodám je tedy třeba odpomoci nejlepším možným způsobem. (Von einer Lehrerin, 1901, s. 272)

Pravý důvod spočíval ovšem ve skutečnosti, že mělo být učitelkám upřeno odstupné za již získané penzijní nároky, „aby učitelské povolání nebylo považováno za přechodné trápení na cestě k získání renty“ (Von einer Lehrerin, 1901, s. 272).

S diskuzí o celibátu učitelek se také vždy objevuje heslo o nadprodukci učitelek, které jsou odsouzeny k beznadějnému čekání na umístění", a s tím spojený požadavek na uzavření vzdělávacích ústavů pro učitelky. Tento požadavek se často uvádí v souvislosti s „klášterními ústavy“, které „s pomocí částečně nekvalifikovaného učitelského personálu masově vychovávají učitelky“ (Das Eheverbot der Lehrerinnen, 1911, s. 8).

Větší přiblížení ženského učitelského personálu k církvi znamenalo pro některé liberály také vyprazdňování nové školy (srov. Říšský zákon o obecných školách) a vedlo k vytvoření bojového hesla o feminizaci školy.

Od roku 1878 bylo dosaženo nasycení učitelského personálu; učitelky narážely při umistování na potíže častěji než jejich kolegové muži (srov. Barth-Scalami, 1995, s. 373).

Učitelka jako manželka se stává v 70. letech 19. století častým tématem. Dokonce i samy učitelky pochybují o tom, že se dá skloubit role manželky s povoláním učitelky. Bartunecková (1877) odkazuje na nutnost svědomité př́ípravy vyučování, na nutné opravy domácích a školních prací a na další vzdělávání, „nebot' klid je krokem zpět“. Tak nezůstane učitelce z celého dne téměř ani hodina, kterou by mohla věnovat rodině (srov. s. 5). Doslovně:

Učitelka přijde ve 12 hodin v poledne ze školy, ale kuchařka byla nespolehlivá; nebot' bez dohlédnutí udělá služebnictvo věci správně jen zřídka. Jídlo je špatné, muž je rozladěn a je z toho scéna. Učitelka musí jít do školy, je možná neusmířena. A nyní má vyučovat. Udělá to, ale jak? Kde se toulají její myšlenky? (Bartuneck, 1877, s. 6) 
Franziska Scholzová (1878), učitelka v Dürnholz an der Thaya (dnes Drnholec), se hlásí jako provdaná učitelka ke slovu na toto téma a odkazuje na skutečnost, že úvazek vyučujících nikdy nepřesáhne 30 vyučovacích hodin a tím zbývá mnoho času na domácí práce. Na druhé straně však pochybuje o tom, zda zbývá dostatek času na zotavení. Scholzová (1878) se „jako rozhodná odpůrkyně staví proti názoru, že svobodná učitelka je svým povoláním více nadšena než učitelka vdaná" (s. 47). Na schůzi dolnorakouského zemského sněmu dne 29. záŕí 1911 se nakonec pro vídeňské učitelky ruší zákaz manželství. Již ve vydání měsíčníku Österreichische Frauenwelt - Rakouský svět žen z 15. ř́ína 1911 bylo zrušení zákazu manželství kriticky komentováno: „Skutečnost, že vydělávající žena v domácnosti a matka musí v mnohém ohledu zanedbávat svůj domov, je zcela nepopiratelná" (Das Eheverbot der Lehrerinnen, 1911, s. 317).

\section{3 Čím byla dána atraktivita povolání učitelky?}

Přes veškeré problémy, se kterými je povolání učitelky spojeno, se již v poslední čtvrtině 19. století rýsoval razantní početní přírůstek učitelek. Je to pochopitelné tím spíše, že dívky byly k maturitě, a tím zároveň (postupně) i ke studiu na univerzitách, připuštěny teprve od roku 1896. Ženy směly od roku 1878 přednášky na univerzitách navštěvovat pouze jako hostující posluchačky. Od roku 1896 byly uznávány doktorské diplomy získané v zahraničí, nostrifikace ovšem proběhla teprve po opakování veškerých rigorózních zkoušek. $V$ tomtéž roce bylo rovněž $\mathrm{v}$ zákonu zakotveno připuštění žen k maturitě. K připuštění ke studiu na univerzitách pak docházelo postupně: Vídeň, Praha, Graz a Innsbruck připustily ženy od roku 1897 ke studiu na filozofických fakultách; v roce 1900 následovalo připuštění ke studiu medicíny. Teprve v první rakouské republice, v roce 1919, získaly ženy možnost studovat práva. Od roku 1928 směly studovat na Evangelické teologické fakultě a od roku 1945 na Katolické teologické fakultě Univerzity ve Vídni (srov. Seebauer, 2007, s. 96).

Vzdělávací ústavy pro učitelky nabízely dívkám/ženám až do počátku 20. století možnost absolvovat uznávané vzdělání přesahující povinnou školní docházku. V krátké době „,vyprodukovaly” vzdělávací ústavy nadbytek učitelek, které se nezřídka musely jako soukromé učitelky „za skývu chleba” tvrdě protloukat životem. Podobný osud potkal (často po dlouholetém studiu) i učitelky cizích jazyků, hry na hudební nástroj a zpěvu. Feminizace učitelského povolání byla tudíž naprogramovaná již předem, ve druhé polovině 19. století (srov. Seebauer, 2014). 


\section{$4 \quad \mathrm{~K}$ feminizaci dnes: veřejný diskurs a pedagogické výzkumy fundované genderovými teoriemi}

Učitelé v primární škole se stali významným tématem. Hovoří se o feminizaci školy a v důsledku toho o „chlapcích, kteří jsou ve školském systému znevýhodněni“. Ve veřejném diskursu tuto skutečnost tisková média i média online neustále potvrzují. Nízký podíl mužských vyučujících se mj. udává jako důvod problematické situace mnoha mladistvých. Argumentace vychází - často nediferencovaně a nereflektovaně - z pedagogické perspektivy; uvádí se: image povolání, nízký společenský status, nízká mzda ve srovnání s jinými tzv. mužskými povoláními, absence kariérních možností, relativně dlouhá doba vzdělávání v poměru k možnostem postupu a odměňování. Naproti tomu se však učitelské povolání považuje za slučitelné s tradičním obrazem ženy a rodiny: vyzdvihuje se především vhodnost pracovní doby pro uspořádání rodinného života; výchova prý přísluší spíše ženám (srov. Bundesministerium für Bildung, Wissenschaft und Kultur, 2005, s. 27) - jde o obraz ženy, který má hluboké kořeny v 19. století.

Přístupy k vysvětlení a argumentaci založené na genderových teoriích odkrývají diferencovaný obraz stran důvodů, proč v učitelském povolání vládne feminizace a jen málo mužů volí vzdělávání k učitelství v primární škole.

- Důvodem, proč tak málo mužů pracuje v „ženských povoláních“, nejsou ekonomická omezení, nýbrž spíše sociální a psychologické konflikty;

- rovněž „osamocenost“ jediného muže v ženském učitelském sboru může být považována za jeden $\mathrm{z}$ důvodů;

- profesní motivace mužů v primárních školách je může vystavit podezření, že jsou pouze „přechodnými“ pracovními silami, které při nabídce atraktivnějších možností zaměstnání změní;

- přítěží je pro muže konflikt, kdy jsou společensky žádoucí jako rolový model a současně vykonávají typickou ženskou práci;

- omezené kariérní možnosti pro ty, kteří neusilují o administrativní pozice, činí učitelské povolání méně atraktivním;

- učitelům primárních škol bývá přisuzována nálepka homosexuality nebo „nedostatečné mužnosti“. 
Na příkladu pečovatelů o děti v Rakousku, určil Georg Augusta (1996) status menšin jako ústřední konflikt v profesním poli, které je spojováno s „ženskostí“. Muži jsou v tomto profesním poli konfrontováni s rozdílnými nároky: na jedné straně mají jako muži odpovídat heterosexuální normě, na straně druhé mají provádět práci považovanou za „ženskou“ (Augusta, 1996, s. 48).

$\mathrm{V}$ důsledku identifikace tohoto problému sestavil Augusta výčet strategií, které pečovatelé o děti používají pro vytvoření hegemoniální mužnosti:

- stáhnout se do určitých částí povolání, specializovat se;

- zdůrazňovat „mužské” prvky své práce (techniku, tělesnou sílu) a vymezit se vůči ženským oblastem působnosti;

- získat odstup tím, že budou na povolání nahlížet jako na přechod k povoláním s vyšším platem, prestiží a větší výzvou; usilovat o dosažení vedoucích funkcí nebo administrativních činností;

- vymezit se vůči práci, nemít žádný nebo nevýrazný vztah k práci.

Paseková (2005) hovoří ve svém výzkumu o profesní motivaci absolventek a absolventů jedné rakouské pedagogické akademie (od roku 2007 pedagogická vysoká škola) obecně o čtyřech typech volby povolání:

- učitelské povolání jako alternativní profesní nebo životní plán, který se projevuje výhradně u mužů a reprezentuje odmítnutí tradičně mužských životních plánů (účastníci výzkumu v interview uváděli, že narazili na možnost stát se učitelem spíše náhodně, na základě osobních kontaktů);

- jako nová orientace nebo změna orientace;

- jako racionální řešení a jako

- jediné povolání, které si respondent přál. (srov. Paseka, 2005, s. 224)

V dřívějším výzkumu však Paseková (1996) zjistila v otázce volby učitelského povolání mezi muži a ženami rozdíly. Týkají se reakce sociálního okolí a slučitelnosti profesního a rodinného života. Jestliže pro muže slučitelnost profesního a rodinného života nepředstavuje skutečný problém, pak

ženy anticipují při volbě povolání konflikty, se kterými se budou setkávat, a volí povolání, o němž mají představu, že připustí - pokud možno bez frikcí - spojení časových a normativních nároků obou světů, na druhé straně jim však umožní dvojí orientaci a ponechá jim otevřené možnosti vydat se oběma směry. (Paseka, 1996, s. 73, cit. dle Bundesministerium für Bildung, Wissenschaft und Kultur, s. 33) 


\section{$5 \quad$ K problematice feminizace / nízkého podílu mužů v primárních školách všeobecně a ve třídách $s$ dětmi s migračním pozadím}

Následně budou v bodech shrnuty obecné výsledky výzkumů, které se zabývají feminizací ve školství (Horstkemper, 1999; Bölsche, 2002; Larcher \& Schafroth, 2004; Thimm, 2004) - týkají se jak pedagogických problémů, tak demografických změn:

- chybějí vzory; pro chlapce chybí orientace na mužské rolové vzory; děti mužského pohlaví nenacházejí partnery a modely stejného pohlaví, s nimiž by se mohly identifikovat;

- nerovnováha mezi pohlavími není v žádném případě žádoucí; rovnoprávné společenství mužů a žen nemůže být $v$ případě nerovnováhy dětem a mladistvým prakticky předvedeno;

- typické dívčí kvality jsou přeceňovány, typické kvality chlapců podceňovány; chlapci jsou již zčásti považováni za diskriminované: úspěšné dív$k y=$ selhávající chlapci (srov. Larcher \& Schafrot, 2004);

- feminizace s sebou nese „ženský“ styl a „ženskou“ kulturu výuky;

- právě ve společnosti bez otců by chlapci potřebovali v primární škole více mužů - např́íklad také proto, aby se zamezilo násilí.

V důsledku přistěhovalectví stoupl v Rakousku na počátku 90. let minulého století a znovu v uplynulých letech počet osob se zahraniční státní příslušností. S příchodem téměř 17800 osob se na tomto procesu nejvíce podíleli Němci, následovaní státními příslušníky Rumunska a Mad’arska (téměř 13 400, resp. 13 100), Polska (7 100) a Slovenska (téměř 6 000). Kolem 48400 přistěhovalců roku 2012 (35\% všech, kteří se přistěhovali) pocházelo z třetích států. Zatímco kolem 15500 přistěhování připadlo na osoby z bývalé Jugoslávie, je počet přistěhovalých z Turecka s přibližně 4100 osobami poměrně nízký. Z ostatních třetích států se přistěhovalo téměř 28900 osob. Počet žádostí o azyl stoupl v roce 2012 na zhruba 17400.

Početní stav zahraničních obyvatel s trvalým pobytem v Rakousku byl 1,004 milionu osob (11,9\% obyvatelstva) a tím zhruba o 52800 osob vyšší než začátkem roku 2012 (Migration \& Integration, 2013, s. 8). 
Podíl migrantek a migrantů (žáků a žákyň s migračním pozadím) se projevuje ve školách: na rakouských školách byly ve školním roce 2011/2012 zjištěny následující počty dětí s neněmeckým hovorovým jazykem (v procentech): primární školy - 24,8 \%; hlavní školy - 21,7 \%; nové střední školy - 27,4 \%; speciální školy - 29,4\%; polytechnické školy - 25,5 \%; všeobecně vzdělávací vyšší školy - 15,3 \% (Migration \& Integration, 2013, s. 45).

Rozložení žákyň a žáků s neněmeckým mateřským jazykem je v jednotlivých spolkových zemích, případně ve vídeňských okresech, skutečně rozdílné: na mnoha vídeňských školách přesáhl podíl migrantek a migrantů již dávno hranici $50 \%$.

Ale vrat'me se zpět $\mathrm{k}$ fenoménu feminizace (srov. Bundesministerium für Bildung, Wissenschaft und Kultur):

- Obzvlášt' chlapci z rodin migrantů, kteří prožili desiluzi, mají problémy s velkým počtem učitelek, mužské vůdčí figury značně postrádají - „protože jim byla autoritářskými otci vštěpována tvrdá pravidla machoismu“.

- Z odborného hlediska by proti ženské převaze nic nemluvilo. Problémy však „vznikají tam, kde žák nebo rodiče neuznávají autoritu učitelky“ míněny jsou děti a rodiče z kultur, jako je turecká nebo kultura zemí bývalé Jugoslávie.

- Speciálně pro tuto skupinu chlapců by bylo třeba nabídnout „alternativní formy mužskosti"; souběžně s tím je vhodné získávat vyučující muže z prostředí etnických menšin.

- Na základě chybějících mužských rolových modelů - především v primární škole - se děti brzy dozvědí, že stát se učitelkou je pro ženy vhodné, což především dívky již brzy vyjadřují jako své přání. Pokud se dívky a chlapci setkají s učiteli a učitelkami ve stejné míře, poznají, že je učitelské povolání stejně významné pro obě pohlaví.

- Z pohledu potenciálních vyučujících mužů je třeba skloubit přání being a real man s being a real teacher, nebot' „praví muži“ nedělají nic „ženského“.

V jednom švédském výzkumu (Blank, 1998) jsou uvedeny argumenty, které byly zmíněny již v historické části tohoto textu: z perspektivy žákyň a žáků jsou vyučující muži mužskými vzory; z perspektivy žen by jak ženy, tak 
muži profitovali z pracovního prostředí, které vykazuje vyrovnaný poměr mezi pohlavími. Kromě toho vyjádřil švédský učitelský svaz (Lärarförbundet) domněnku, že kdyby učitelské povolání volilo více mužů, mzdy by v této profesní skupině stoupaly. Podle výzkumu v oblasti pracovních míst bylo na pracovních místech s vyváženým zastoupením mužů a žen zjištěno méně absencí z důvodu onemocnění nebo byly tyto absence krátkodobější; zlepšuje se dobrá atmosféra i výkony (Blank et al., 1998, cit. podle Bundesministerium für Bildung, Wissenschaft und Kultur, 2005, s. 27).

\section{Epilog}

O nápady a/nebo strategie, jak zvýšit podíl mužů na rakouských školách, by nebyla nouze: týkají se zvýšení prestiže učitelského povolání, mj. i zvýšením platů učitelek a učitelů na primárních školách a pozitivní diskriminací v podobě přednostního přijímání učitelů na primární školy. Paralelně ke Girls' Day, který má motivovat dívky ke studiu technických oborů, by mohly být pořádány Boys' Days, které by motivovaly mladé muže k volbě povolání pedagogů/pečovatelů.

Ani cílené získávání mužů a slibování vyhlídky dobrých profesních možností mužů na aktuálních volbách povolání však nic nezměnilo. Zakládající rektorka Pedagogické vysoké školy ve Vídni uvedla v roce 2009 následující čísla: ve studiu učitelství pro primární školy je sedm až devět procent studujících mužů; v oblasti učitelství pro hlavní školy je to 15-17\%. Speciální informační den pro muže přinesl zvýšení přihlášek pro oblast hlavních škol; u přihlášek pro primární školu byla registrována pouze jedna přihláška navíc oproti roku 2008 (srov. Frauen und Männer gleichermaßen geeignet, 2009).

V době akutního nedostatku učitelů, kdy studující učitelství již v 5. a 6. semestru nacházejí na školách zaměstnání v podobě částečných úvazků, by se měl výzkum učitelského vzdělávání zaměřit na problém kvality výuky! Ten musí konec konců zahrnovat i genderovou otázku.

\section{Literatura}

Augusta, G. (1996). Zur Konstruktion von Männlichkeit bei Männern in weiblich konnotierten Berufen am Beispiel Kinderbetreuer. (Diplomarbeit). Wien: Universität Wien.

Bachmann, F. (1877). Gegner der Lehrerinnen. Allgemeine Zeitschrift für Lehrerinnen, 1(12), 121-122. 
Barth-Scalami, G. (1995). Geschlecht: weiblich, Stand: ledig, Beruf: Lehrerin. In B. Mazohl-Wallnig (Ed.), Bürgerliche Frauenkultur im 19. Jahrhundert (s. 343-400). Wien: Böhlau.

Bartuneck, L. (1877). Die Lehrerin als Ehefrau. Allgemeine Zeitschrift für Lehrerinnen, 2(1), 5-6. Blaschke, T. (1880). Frau Lehrerin. Allgemeine Zeitschrift für Lehrerinnen, 4(23), 175-176.

Bölsche, J. (2002, 9. 10.). Zuchtstation für dumme Machos. Spiegel online. Dostupné z: http:// www.spiegel.de/schulspiegel/boese-buben-kranke-knaben-2-zuchtstation-fuer-dummemachos-a-217209.html

Borschitzky, F. (1911). Referat, erstattet in der allgemeinen Versammlung der Lehrerinnen Wiens am 19. Dezember 1911. Mitteilungen des Vereines der Lehrerinnen und Erzieherinnen in Österreich, 6, 1-6.

Bruneforth, M., Herzog-Punzenberger, B., \& Lassnigg L. (Eds.). (2013). Nationaler Bildungsbericht Österreich 2012. Graz: Leykam.

Bundesministerium für Bildung, Wissenschaft und Kultur (Eds.). (2005). Männer als Volksschullehrer. Wien.

Das Zölibat der Lehrerinnen. (1911). Zeitschrift für Frauen-Stimmrecht, 1(8), 8.

Die Lehrerin als Amtskollegin. (1879, 6. November). Neue Freie Presse, Abendblatt, 4.

Eine Lehrerin. Unterlehrerinnen. (1899). Dokumente der Frauen, 1(1), 10-17.

Frauen und Männer gleichermaßen geeignet (2009, 29. April). Der Standard. Dostupné z http:// derstandard.at/1240550154557/Frauen-und-Maenner-gleichermassen-geeignet

Hany, E. (1912). Die Forderungen der Wiener Lehrerinnen. Österreichische Frauen-Rundschau. Offizielles Organ der Vereinigung der arbeitenden Frauen, 98, 4-5.

Horstkemper, M. (1999). Pädagogik als weibliches Arbeitsfeld - eine Erfolgsstory dieses Jahrhunderts? Pädagogik, 12(1), 31-34.

Kraus, S. (1900). Lage der Lehrerinnen in Österreich. Dokumente der Frauen, 4(14), 428-439.

Larcher, S., Schafroth, K. (2004, 20.1.). Die Bildungsfrage - auch eine Geschlechterfrage. Neue Züricher Zeitung.

Migration \& Integration - Zahlen, Daten, Indikatoren 2013. (2013). Wien: Statistik Austria. Dostupné z: file:///C:/Users/Vichova/Downloads/migration_integration_2013.pdf

Nauheimer, S. (1912). Die neue Lehrer-Gehaltsregulierung. Zeitschrift für Frauenstimmrecht, 2(1), 3-4.

O. A. (1879). Die guten Prüfungsresultate der Lehrerinnen. Allgemeine Zeitschrift für Lehrerinnen, 3(3), 17-19.

O. A. (1911). Das Eheverbot der Lehrerinnen. Österreichische Frauenwelt. Monatsschrift für die gebildete Frau, 1(10), 317.

O. A. (1912). Die Gehaltsregulierung und die Wiener Lehrerinnen. Zeitschrift für FrauenStimmrecht, 2(2), 2-3.

O. A. (1913). Der Gleichberechtigungskampf der Wiener Lehrerinnen. Zeitschrift für FrauenStimmrecht, 3(3), 2-3.

O. A (1914). Epilog zur Gehaltsbewegung der Wiener Lehrerinnen. Österreichische FrauenRundschau. Offizielles Organ der Vereinigung der arbeitenden Frauen, 122, 5-6.

Paseka, A. (1996). "Weil die Kinder so lieb sind..." Über die Berufsmotivation von zukünftigen VolksschullehrerInnen. (Projektbericht). Wien: BMUkA. 
Paseka, A. (2005). Rekonstruieren - verstehen - interpretieren - verdichten. Auf der Suche nach personalisierten Sinnkonstruktionen und latenten, gesellschaftlich determinierten Sinnstrukturen in Aussagen von zukünftigen Lehrer/innen. In A. Kowarsch \& K. Pollheimer (Eds.), Professionalisierung in pädagogischen Berufen (s. 223-230). Purkersdorf: Verlag Brüder Hollinek.

Prausek, V. (1868). Die Verbesserung der Volksschule mit besonderer Berücksichtigung Österreichs. Wien: Sallmayer.

Scholz, F. (1878). Die Lehrerin als Ehefrau. Allgemeine Zeitschrift für Lehrerinnen, 2(6), 47-48.

Schmidt, A. (1877). Lehrer und Lehrerinnen in einem Lehrkörper. Allgemeine Zeitschrift für Lehrerinnen, 1(3), 1-3.

Schwarz, M. (1910). Die Wiener Lehrerinnen und die jüngste Gehaltsregulierung. Der Bund. Zentralblatt des Bundes österreichischer Frauenvereine, 5(2), 1-4.

Schwarz, M. (1914). Abschluss der Gehaltsbewegung der Wiener Lehrerinnen. Der Bund. Zentralblatt des Bundes österreichischer Frauenvereine, 9(7), 7-9.

Statistik Austria. (2013). Lehrerinnen und Lehrer in Österreich. Dostupné z http://www.statistik. at/web_de/statistiken/bildung_und_kultur/formales_bildungswesen/lehrpersonen

Seebauer, R. (2007). Frauen, die Schule machten. Wien: LIT.

Seebauer, R. (2014). Lehrerinnen - Gleichbehandlung, Aktivitäten, Ideen. Zur Sozialgeschichte einer Berufsgruppe mit besonderer Berücksichtigung der Wiener Verhältnisse. Wien: LIT.

Thimm, K. (2004, 17. Mai). Angeknackste Helden. Der Spiegel.

Virgo (1898, 6. Jänner). Die Volksschullehrerinnen. Arbeiterinnen-Zeitung, 2-3.

Von einer ehemaligen Voluntärin (1899). Die Voluntärin in den Privatschulen. Dokumente der Frauen. 1(2), 32-36.

Von einer Lehrerin (1901). Eheverbote und Eheconsense. Dokumente der Frauen, 5(9/10), 270-274.

Wichodil, A. (1879). Unsere Lehrerinnen-Bildungsanstalten. Allgemeine Zeitschrift für Lehrerinnen, 3(21), 161-162.

Zur Besetzung der Lehrerstellen in Wien. (1895, 1. Juli). Österreichische Lehrerinnen-Zeitung, 201-202.

\section{Autorka}

Doz. Dr. hab. et Mag. Renate Seebauer B.Ed. Prof. PH, Pädagogische Hochschule Wien, Institut Allgemein bildende Pflichtschulen; Grenzackerstraße 18, A-1100 Wien, Email: renate.seebauer@phwien.ac.at; renate.seebauer@utanet.at 


\title{
Female teachers: Their long road to equality and acceptance with a focus on feminization and its consequences
}

\begin{abstract}
Starting from the current situation of feminization in Austrian schools the long road to equality and acceptance of female teachers is traced on the basis of historical pedagogical journals for the period from 1870 to the end of the First World War. The roots of feminization - especially in the area of primary schools - go down into the dark depths of the 19th century. Despite resistance from male colleagues and difficult working conditions, being a "female teacher" was the possibility to receive a highly appreciated education after compulsory schooling as girls/women were allowed to take the "Maturity Exam" ("Matura" = entitlement to study at a university) not before 1896. In a short time, therefore, teacher training institutions for women "produced" a surplus of female teachers, who often had to earn their poor living as private teachers - "for peanuts". The high degree of feminization today - and as a result - the lack of male teachers in Austria's primary schools rather often deprive boys the chance to focus on male role models; male children find no same-sex models they could identify with; immigrant boys - especially from other cultures - appear to be particularly affected. Gender-based explanations and lines of argumentation show a variegated pattern why the teaching profession is characterized by feminization; just a few men choose the option to study at a School of Education in order to become a primary school teacher. Quite a lot of what has been published in recent studies (appointment of schoolheads, occupational psychological aspects...) can already be found in papers around the turn of the 20th century.
\end{abstract}

Keywords: feminization, discrimination, equality, celibacy of female teachers, gender-theoretical explanation

Píšová, M., Hanušová, S., Kostková, K., Janíková, V., Najvar, P., \& Tůma, F. (2013). Učitel expert: jeho charakteristiky a determinanty profesního rozvoje (na pozadí výuky cizích jazyků). Brno: Masarykova univerzita.

Kniha je (po publikaci Teorie a výzkum expertnosti v učitelské profesi, 2011) druhým knižním výstupem projektu, který se zaměřoval na charakteristiky i dosahování a udržování expertnosti učitelů (v konkrétní subkultuře učitelů cizích jazyků). Dohromady tyto dvě publikace přinášejí ucelený pohled na poměrně rozsáhlý výzkumný počin, který byl zarámován designem vícečetné prrípadové studie a zahrnoval pět studií, jež se každá svým specifickým způsobem snažila rozkrýt určitou konkrétní dimenzi učitelské expertnosti. 